ljtihad: Jurnal Wacana Hukum Islam dan Kemanusiaan

Vol. 20, No. 2 (2020), pp. 191-.210, doi : 10.18326/ijtihad.v20i2.191-210

\title{
Women and advocacy: study of the Ahmadiyya community in Tasikmalaya
}

\author{
Inasshabihah \\ Center for Religious and Cross-Cultural Studies, Universitas Gadjah Mada, Yogyakarta \\ E-mail:inasshabihab@ugm.ac.id \\ DOI: 10.18326/ijtihad.v20i2.191-210
}

Advocacy against Ahmadiyya Indonesian Congregation (JAI) has been carried out in Tasikmalaya, West Java, both internally and externally to resolve various forms of intolerance, including mosques sealing and marriage registration. This research highlights the contribution of Ahmadi women with their experiences and efforts in the advocacy process through the concept of Agency and advocacy based on two approaches: Rights and Social Inclusion. This research shows that, 1) the experience of being a victim of intolerance is able to transform women from objects into subjects of advocacy and play a role in advocating themselves and their groups, and 2) internal advocacy is important to provide legal understanding to survivors to increase the awareness of Rights within groups. Therefore, women can contribute positively to the ongoing advocacy works.

Advokasi terhadap Jemaat Ahmadiyah Indonesia (JAI) telah dilakukan di Kabupaten Tasikmalaya, Jawa Barat, secara internal maupun eksternal guna menyelesaikan beragam bentuk intoleransi yang terjadi, termasuk penyegelan masjid dan pendaftaran pernikahan. Riset ini menyoroti kontribusi perempuan Ahmadi dengan pengalaman dan upayanya dalam proses advokasi melalui kerangka konsep Agensi dan advokasi berbasis pada dua pendekatan: Hak dan Inklusi Sosial. Hasil penelitian ini menunjukkan bahwa, 1) pengalaman menjadi korban intoleransi mampu mengubah perempuan dari objek menjadi subjek advokasi dan berperan dalam melakukan advokasi bagi dirinya dan kelompoknya, dan 2) advokasi internal penting dilakukan untuk memberikan pemahaman hukum kepada penyintas untuk meningkatkan kesadaran Hak dalam kelompok. Oleh karena itu, perempuan dapat berkontribusi secara positif dalam kerja advokasi yang sedang berlangsung.

Keywords: women advocation; Ahmadiyya Indonesian congregation; advocacy of religious group. 
Ijtihad: Jurnal Wacana Hukum Islam dan Kemanusiaan, Volume 20, No. 2, Desember 2020: 191-210

\section{Introduction}

Ahmadiyya is one of the marginal groups that experiencing minorityization, in which there is "a process of discrimination, and even persecution, of minority groups at the legal, political, social and intellectual levels" (Mudzakkir, 2011:2). In the national context, the Blasphemy Law (Number 1/ PNPS/1965) and two MUI fatwas concerning Ahmadiyya's heresy in 1980 and 2005 triggered intolerance towards Ahmadi. The number of intolerance increasing in various regions in Indonesia especially when the government issued a Joint Decree (SKB 3 Menteri) involving the Minister of Religion, the Minister of Home Affairs, and the Attorney General in 2008 concerning Warnings and Orders to Adherents, Members and/or Members of the Administrators of the Ahmadiyya Indonesian Congregation (JAI) and Community members, more or less contain orders for JAI members to stop spreading Ahmadiyya teachings and stop their activities that considered deviate from Islamic teachings. The Decree becomes the basis for the emersion of similar regulations in some places including West Java Governor Regulation (Peraturan Gubernur) Number 12 Year 2011 concerning Prohibition of Activities of the Ahmadiyya Community in West Java.

The number of intolerances increased then. From the data compiled by Farsight, Setara Institute, and Fahmina Institute in 2017, there are several forms of intolerance in West Java including physical violence by the government and state apparatus (90.53\%), physical violence by surrounding environment $(90.73 \%)$, eviction $(87.42 \%)$, threats or humiliation on social media $(80.13 \%)$, physical threats from the government and apparatus $(73.51 \%)$, bullying $(73.51 \%)$, physical threats by the surrounding community $(72.85 \%)$, physical violence by mass organizations $(70.86 \%)$, discrimination by the government $(51.65 \%)$, threats of violence from mass organizations (47.02\%), and verbal expressions of hatred (39.74\%) (Bhaskara, 2019).

The impact of intolerance is also experienced by women. Women, who are considered to be a central figure in households and building social relations in the community arounds, have to deal with challenges and encounter intolerance actions. Previously, research on Ahmadi women was focus on the viewpoint of the defense mechanism carried out by Ahmadi women through Lajnah Imaillah (LI), an Ahmadi women's organization. LI works to empower their members through religious and social activities. They began to involve into 
social activities with wider communities outside their community, but still in limited numbers (Noor, 2014: 71). This paper will explain more about the involvement of Ahmadi women in the advocacy process both in internal and external, improve their legal understanding, then contribute to access their rights.

In West Java, precisely in Tasikmalaya District, Ahmadiyya cooperates with Lakpesdam NU (Nadhlatul Ulama Institute for Research and Development of Human Resources) and DPC Peradi (Branch Board of Advocates Association of Indonesia Advocates) Tasikmalaya to advocate the cases of mosque sealing and marriage registration. The advocacy process has been going on and obtained some progresses though not fully done yet, but there are challenges that must be solved first to arise a common perception and awareness of the civil rights. To deal with those challenges, Ahmadi advocates internally within its group before carrying out advocacy against external parties, especially those who have been assimilating their rights. During internal and external advocacy, women were transformed and contribute through important roles.

This paper will discuss the types of intolerance towards Ahmadi women in Tasikmalaya Regency. Followed by, how the involvement of Ahmadi women in Internal Advocacy which included challenges in the process of building rights awareness within JAI's internal circles. Continued with, the works of Ahmadi women in the External Advocacy where they have been transformed into subjects and involved in dealing with JAI issues related to the case of mosque sealing and marriage registration, by directly meeting the parties involved such as the P3N Officers and Village Head. Based on the findings, internal advocacy or in this case represented through the concept of self-advocacy becomes an important point for the sustainability of JAI advocacy. After building the awareness from within, the external civilization efforts to village officials, local government, and other excluders have been done more optimally. Women in this case are the Change Agents who empowering each other and able to join the advocacy.

\section{Method}

The research was conducted in Tasikmalaya Regency, West Java, precisely in Kersamaju Village. Kersamaju village is inhabited by $70 \mathrm{JAI}$ members and lives in several RT 
(Neighborhood Association) in the village. Kersamaju was chosen to be the main village in this research because there is a case of mosque sealing and difficulties in registering marriages in Kersamaju. Despite the focus in Kersamaju, this study also describes the conditions of JAI members in other villages namely Tenjowaringin and Sukapura regarding the discrimination they receive and the experience of women negotiating with their identities. This research is part of collaboration with The Asia Foundation, Lakpesdam NU Tasikmalaya, DPC Peradi Tasikmalaya, and CRCS Universitas Gadjah Mada, Yogyakarta. The three research villages are assisted villages of Lakpesdam NU and DPC Peradi Tasikmalaya.

\section{The intolerancies towards Ahmadi women}

There are at least eight forms of intolerance experienced by Ahmadi women in Tasikmalaya. First, harassment. As an Ahmadi in Sukapura, J's family had experienced harassment, for example when her brother and mother walked in front of their neighbor's house, they heard the neighbor throwing saliva and said, "Cuih, anjing (dog)." When she was in elementary school, a friend once deliberately sang the Mars of FPI (Islamic Defenders Front) song in front of $\mathrm{J}$ to mock her. In high school, a teacher in her class raised a topic about the misguidance of Ahmadiyya. In Tenjowaringin and Kersamaju, Ahmadiyya children also being mocked by friends or neighbors as a heretical group.

Second, hate speech. Since 2013 until 2017, religious preachers who deliver Islamic teaching monthly during recitals (pengajian) in villages spread hate speech against JAI, including calling Ahmadiyya as a group of infidels, apostates, and "their blood are halal." In Kersamaju and Tenjowaringin, they even made fake news about Ahmadiyya like, if there are JAI resident who died then their body would only be thrown away like dog.

Third, exclusion. In Sukapura, $J$ and Ahmadi children are prohibited from participating in the Islamic boarding school (pesantren kilat) during Ramadan. The local DKM (Dewan Kesejabteraan Masjid/Mosque Prosperity Council) prohibited Ahmadi to enter the mosque where the teaching takes place. Likewise, Ahmadi children in Kersamaju were bullied while playing in the village.

Fourth, terror. On the Eid night in Kersamaju, a group of people ride motorbikes and repeatedly passed Ahmadi houses while shouting curses and threats. "Since 9 p.m. (motorbikes) passed and 
shout angry and intimidate words, there are many motorcycles, cars, noisy muffler. (They) come from above. Shouting, 'Ahmadi, convert! The infidel! Dog! Convert quickly! Istighfar!" said E, Ahmadi in Kersamaju. The terrorist also got off the motorbike and danced around the Ahmadi houses, made them felt very disturbed. Some people also threw firecrackers towards the Al-Furqon Mosque, which is the Ahmadi mosque. The sound of the bike's muffler was so noisy and made an Ahmadi daughter traumatized. "When hear noisy muffler, my child grabs her blankets, shaking, scared," said A. In Sukapura, the tension between Ahmadi and mass organizations such as FPI is still intense. The majority of villagers are NU residents who affiliated with FPI. Every Eid, the Ahmadi have to go to the mosque far away from their house right after dawn so nobody would saw them. They walked like a thief because they were haunted by terror.

Fifth, attack and destruction. In 2007, the Basyarat Mosque in Sukapura was destructed by intolerant groups. The attacked mosque was located in Tarunajaya Village, right next to Sukapura. According to J, Tarunajaya was inhabited by majority of FPI members and supporters. This becomes a polemic until now, because even though the majority of the Ahmadi are living in Sukapura, their mosque is located in Tarunajaya.

Meanwhile, in 2013, there was an attack towards Ahmadi in Tenjowaringin when they held an annual event called Jalsah Salanah. In the incident, there was no backlash from Ahmadi because they believed that physical "resistance" was strictly prohibited. The mob also went down towards the Baitus Subhan Mosque, Citeguh, Tenjowaringin, and destroyed the mosque with samurai, stones, and machetes. According to I, Ahmadi women from Tenjowaringin, the incident caused one victim from the intolerant mass that died after being crushed by a glass window which he brokes himself. Ahmadi who witnessed the attack was traumatized to the point of trembling and not able to stand.

In Kersamaju, for many times Ahmadi women hear the information about some plan to attack them. Usually there was someone who leak the information to Ahmadi. But the information was not always proven to be true. The attack didn't happen even though the Ahmadi women had prepared themselves, keep their important letters in bags and prepare their clothes.

Sixth, mosque sealing. In Sukapura, intolerant mass sealed and damaged the Basyarat Mosque in 2007 and asked Ahmadi to sign a letter saying that they will not do any worship in the village. The Ahmadi then looked for other alternatives and they moved to worship at the house of Y. In 2010, the intolerant mass again asked to them to sign a declaration that they will 
not hold any worship activities in the area of Sukaraja. Few years later, the destroyed mosque which was left in ruins had been used for a worship. Suddenly in 2014, it was forbidden to carry out religious activities even in the destroyed mosque. Some time later, an Ahmadi gave his house as a temporary prayer center so Ahmadi can use it to pray. Of course, that doesn't solve the problem. "They have to be clandestinely (worship at the Prayer Center), because it is not safe. We must set some tactics to do our activities smoothly," said J.

Mosque sealing also happened in Kersamaju. In 2015, Ahmadi wanted to renovate the AlFurqon Mosque which had been attacked around 2001. The renovation plan in 2015 received negative response from community leaders and local residents because they have no Building Permit (Izin Mendirikan Bangunan/IMB). The problem is, even when they want to register the IMB, they are not facilitated by village apparatus. A few months later, local apparatus sealed the mosque without giving prior notice. Ahmadi tried to open the seal because it was considered illegal, but soon the authorities came and sealed the mosque again. In the second sealing, JAI residents became more helpless after they saw the officers carrying security shields and barbed wire.

Seventh, barrier to register marriage. The difficulties in registering marriages occur in almost all villages in Tasikmalaya Regency, except in Tenjowaringin which is one among the reasons because the village is inhabited by Ahmadi in majority, including the Village Head. Since 2013, Ahmadi in Kersamaju experienced difficulties because the Marriage Registration Assistant (Petugas Pembantu Pencatat Nikab/P3N) Officer who is part of Religious Affairs Office (Kantor Urusan Agama/KUA) has refused to handle the marriage of JAI residents. Registration only can be done if Ahmadi signs a statement letter that they are "not the members of Ahmadiyya community." Ahmadi choose to marry in Tenjowaringin which facilitate the marriage registration for Ahmadi, although it will be more troublesome because they have to deal with more paperworks. The officer, $\mathrm{O}$, is also a religious figure who sealed the Ahmadiyya mosque. $\mathrm{O}$ is highly respected and his influence is even stronger than the Village Head of Kersamaju.

Eighth, job limitations. In Tenjowaringin, an elementary school teacher who is a JAI member can not apply to be a school principal because there is a letter from people who claim themselves as the "community" stating that the schools cannot accept Ahmadi as principle. 


\section{Advocacy: the approaches and women as the change agent}

There are numbers of approaches in advocacy, including the Rights Approach and Social Inclusion Approach. Related to Freedom of Religion and Belief (Kebebasan Beragama dan Berkeyakinan/KBB) cases, a Rights-based approach is more often used but there is a potential to turn the victim into perpetrator and canceling their rights. Because, this advocacy has the potential (not necessarily happening but potentially) to victimize victims, when victims are being sacrificed again in the process because they are considered guilty or considered as the cause of the action they experienced (Panggabean, et.al., 2014: 60). In the Cikeusik case, for example, Ahmadis were sentenced to six months in prison, similar to the sentence handed down by the Serang High Court Judge to all defendants who attacked and killed six Ahmadi in Cikeusik, Banten, in 2011.

On the other hand, to achieve comprehensive and intensive advocacy in KBB case, mediator should consider Social Inclusion approach. Social Inclusion is a process of building social relations and respecting individuals and groups that they can participate fully in decision making, economic, social, political, and cultural activities, and are equal in accessing and controlling resources (to fulfill basic rights) in order to feel the standard of decent living welfare in the community (Maarif, et.al., 2019: 5).

The objectives of Social Inclusion are summarized in three points, 1) increasing access to social services and acceptance; 2) increasing fulfillment of human rights; and 3) improving policies for social inclusion. To support these goals, three areas of advocacy were also formulated, namely 1) social acceptance; 2) service; and 3) policy. In practice, advocacy based on Social Inclusion emphasizes three elements. First, the element consists of three domains, namely policy, service, and acceptance. All three areas are equally important, no one is more important than the others. Second, subjects from each area are treated as "potential partners." The intended subjects in this case are individuals who are attached to authority in the realm of advocacy: subjects of services are the state civil apparatus, subjects of policies are the policy makers, and subjects of acceptance are related to citizen groups: includer, excluder, and mediator, which includes activist actors from various issues. The involvement of subjects as potential partners enables them to transform from an excluder who stand in "contra" side becomes more caring, accompany, and able to defend the marginalized groups involved.

The third element of Social Inclusion is the strengthening of the community which becomes the substance as well as the target of strengthening social relations among the assisted residents. 
By strengthening the assisted community, recognition, protection, and state services that can be inclusive for all citizens including marginalized groups such as the indigenous religions and in this case the Ahmadi, can be realized.

In Kersamaju, Lakpesdam NU and DPC Peradi develop advocacy through several activities. In terms of advocating for the Rights-based approach, DPC Peradi held a Paralegal Training class. DPC Peradi also initiated the Posbakum (Pos Bantuan Hukum/Legal Aid Post), Kadarkum (Keluarga Sadar Hukum/Family Aware of Law), and RBM (Rehabilitasi Berbasis Masyarakat/Community-Based Rehabilitaion) in the assisted villages including Kersamaju. The programs are designed to improve citizens' legal understanding and as a strategy to create inclusiveness between JAI members and the village residents. In compiling the management structure of the programs, DPC Peradi combined JAI and non-JAI residents to trigger positive new relations between regardless of their background, and worked together to develop their village. Meanwhile, Lakpesdam NU's activities focus on building social relations through Citizens Forum, mediation, building consolidation networks with legal aid institutions, and community-based paralegal training.

This combination of Social Inclusion and Rights-based approaches has a progressive impact. Paralegal Training proved to be able to increase the understanding about protection for minority groups through the law, while the cultural approach did by Lakpesdam NU helps Ahmadi to openly communicate with village residents, actively engage directly with communities, and building relationships with Village Apparatus.

The contribution of Ahmadi women indeed important. In the case of religious minority advocacy, women are vulnerable to being affected because women's voice and position are often marginalized, which is an irony because in daily activities women who mostly stay and working at home are very vulnerable to face intolerance. In other way, women also have access to involve in central activities in village such as Family Welfare Movement (PKK) and Integrated Healthcare Center (Posyandu) where they can engage with residents. That's why women's contribution in advocacy is important.

Their involvement in advocacy changes women into agents of themselves and their groups. The Change Agent concept from Margaret Archer can be interpreted that an agent is the one who create changes individually and collectively and expected to change the live level of the community through interaction. Change agent itself is a term used to refer to the main causes of events, the 
driving force who responsible for their own destinies, which drive social dynamics and lead to transformation in society (Gani, 2011: 19-21).

Change agent will able to change or maintain structure and culture through interaction. Interaction in this case is defined as an idea, input, or agent experience that is accepted and adopted by society which then creates action, and that action results in elaboration and change. Therefore, the agent is possible to produce reproduction and transformation (Margaret Archer, in Chadijah, et al.: 2020: 112). The transformation that occurred in this case is the Ahmadi women who initially did not respond positively to advocacy, became more understand about what they need to do through empowerment, and became agents of change by supporting the advocacy process and even being actively involved in it.

By empowering women, they can build their personal and group capacities, instill confidence, socialize their understanding and skills. Thus, women's empowerment has the potential to transform women from affected ones into actor of advocacy and make them able to empower others, and finally involved in the struggle to demand their rights. Empowered women will be able to become an agent for herself to participate in eliminating the losses of women in situations of intolerance, as well as eliminating discrimination against women.

In Kersamaju, the majority of Ahmadi men are working outside the city for quite a long time. If there's a visit from excluder like police or any parties who against Ahmadiyya, or even terror and assault, only Ahmadi women who will be at home. Even around the Al-Furqon Mosque there are only few old Ahmadi men and they are unable to communicate effectively with excluders. If JAI Kersamaju only relies on vocal central figures such as $\mathrm{N}$ or $\mathrm{D}$, it will be difficult because $\mathrm{N}$ and $\mathrm{D}$ live in another part of the village. So, women empowerment is important so Ahmadi women can learn the legal understanding and the ability to negotiate with excluder. Moreover, the excluder will come anytime. For this reason, it is important for women not to remain silent and only rely on men. It is important for Ahmadi women to have the ability to handle problems without too dependent on others.

"Very important (for women to come forward). It is urgent. Women also need to know what's happened in the outside. If we just stay quiet, then all of sudden... we can't just rely on men. So if suddenly, like the case in Kersamaju mosque, if suddenly there are people (intolerant ones) who come continuously... while the men are working outside. If we don't take a step, who can deal with them (excluders)? Why do you want to rely 
on men while the men are not there? So, we need too. We need to move. If you just stay quiet, just waiting, it won't change anything." $-\mathrm{N}$

In 2016, Ahmadi women from Kersamaju, N, accepted the invitation from Bandung Legal Aid (LBH Bandung) to join Paralegal Training in Bandung. The training held also for marginal groups such as Shia, LGBT, et cetera. In other hand, her husband, D, joined Paralegal Training held by DPC Peradi. After the training, both of them try to continue the mosque renovation since they now aware that the seal might be illegal and the state should protect their rights to do worship according their beliefs. But, there was a resistance coming from within the JAI members who felt that renovation was not necessary because the condition was safe and there was no conflict with the village or the local government again. While according to $\mathrm{N}$ and $\mathrm{D}$, renovation should be continued because worship is a basic right of Indonesian citizens protected by law. The condition is only safe if the Ahmadi don't have to sign any paper before register their marriages and if they can worship in their mosque freely, with no seal.

\section{The challenges and the strategies of internal advocacy}

Before participating in a larger scale of advocacy process, internal advocacy for the community need to be done first so all the parties have same understanding of what advocacy is, what is the importance of being involved in the advocacy process, what rights they need to fight for, what are the government's obligations in these issues, and what they need to do. Thus, the survivors are educated and able to contribute positively to the advocacy process.

The challenges of advocacy are long-lasting trauma and fear. This fear occurs because of the conflict between Ahmadis and villagers which caused them not be able to socialize optimally in the surrounding environment. Most Ahmadi do not talk about the trauma and choose to hide it away. Unsolved trauma makes Ahmadi more passive in advocacy because they fear to step up.

In all three villages, the fear arose because they felt threatened especially after they witnessed the mosque destruction or experiencing terrors. In Kersamaju, the village apparatus seemed to be an actor of this intolerance, close their eyes to the discrimination that occurred. Fear also makes Ahmadi women like I and J hesitated to open their identity as Ahmadi. 
Second, stigma against legal process. Ahmadi has a contrary perspective about legal process, that taking legal action will only make them lose especially after the incident in Cikeusik when Ahmadi as victim was jailed even though they were clearly victims. Third, the doctrine to not "fight back" including against those who hurt them. For J, the principle to not "fight back" believed by Ahmadi is basically a good one because they reject the use of violence. However, this principle has the potential make Ahmadi more passive and powerless in responding to intolerance. Fourth, gender mainstreaming is not easy to do because of JAI's management structure. As an organization, JAI has an official and standard management structure. It potentially difficult for women to involve in advocacy process and in the other way, each member of JAI has their respective roles.

Fourth, difficulties in socializing legal understanding to internal JAI member. As the actor of advocacy, $\mathrm{N}$ found it difficult to socialize the understanding of law in the form of articles and theories to fellow Ahmadi women because of their unfamiliarity with legal terms. $\mathrm{N}$ herself has no legal background and just learned it in Bandung Legal Aid. Instead of legal theory, $\mathrm{N}$ felt that Ahmadi women needed more instructions to act against excluders because she felt that understanding the law was not fully effective in their daily activities. On the other hand, the legal theory still important as a foundation to convince the Ahmadi that they are protected by the law. The challenges above not only occur in Kersamaju but also Sukapura. While in Tenjowaringin, the process to increase awareness of rights to JAI members is easier, and one of the factors is that there's no shortage of human resources since the majority of the population are Ahmadi.

In order to respond the resistance, challenges, and to increase awareness and understanding of the law and the rights of citizens, N, D and Ahmadi members who already aware of the issues have begun to arrange internal advocacy programs including Awareness Class and Socialization of Legal Understanding. In collaboration with "Sobat KBB" (Solidaritas Korban untuk Kebebasan Beragama dan Berkeyakinan/Victim Solidarity for Freedom of Religion and Belief), a month-long Awareness Class (Kelas Kesadaran) was held at Kersamaju in 2016. The basic learning is about freedom of religion and belief and understanding of the law. In the class, facilitator reminded Ahmadi that they have the right to worship and practice their belief. They were given the understanding that everyone has 
a role, including Ahmadi women.

The Awareness Class and Paralegal Training is part of self-advocacy which refers to an individual skill in communicating effectively, expressing opinions, negotiating, expressing their interests, desires, needs, and rights, as well as the ability to make decisions and be responsible for decisions taken (Van Reusen, et.al, 1994; Van Reusen, 1996; Schreiner, 2007; Test, et.al, 2005, as quoted from Ahmad, 2013: 191). A sufficient legal understanding will evolve a safe feeling, forming emotional and intellectual maturity so it will be more convenient for women to contribute in advocacy strategies, make decisions, and engage in problem solving process. Without an equal awareness, the advocacy process will be hampered.

$\mathrm{N}$ also engages in internal advocacy by individually socialize the knowledge to strengthen their basic understanding of law and continuously strengthen rights awareness for Ahmadi women by sharing the basic understanding she learned during the Paralegal Training, including the rule of law, articles relating to religious freedom, places of worship, plot of legal case complaints, and so on. $\mathrm{N}$ disseminated her knowledge through internal forums of Ahmadi women such as weekly recitation or when she visited the homes of JAI members.

Ahmadi women started to understand that they should not experience discrimination, and advocacy doesn't mean to disturb the peace in the village or "seeking attention" but rather to open an understanding that there is a legal/political/social system that marginalizes them, and if they stay silent about it the state restrictions might happen again.

Women's experiences as the one who mostly stay at home become a greater challenge, because they are responsible to take care of their children. As in the case of Ahmadi women called A, her child was traumatized by the motorbike terror in front of her house every night on Eid. The terror makes her child panic every time she heard any muffler sounds. But there are many mountain bikes passed their house every day. A finds it as her strategy to remedy her child's trauma. "So when mountain bikes passed by, it's an opportunity for trauma healing. I said to my daughter, 'that's the sound from yesterday (from the Eid terror)." Since then, her daughter's trauma was gradually reduced. In addition, children are also vulnerable as victim that abused by other residents in the village. Ahmadi women feel the need to defend their children against the abuser. Paralegal training and Awareness Class 
helped Ahmadi, especially women, to build a different paradigm in seeing the legal issues they experienced.

The condition is pretty different in Sukapura. DPC Peradi and Lakpesdam NU have been advocating JAI Sukapura through Paralegal Training. However, the continuity of advocacy programs has not been optimal because of the psychological conditions of JAI members who are still dominated by fear and lack of actors in Sukapura. The stigma that they are marginalized group who will not be heard is still strong. Ahmadi women, according

to J, need to get legal counseling because they spend more time to handle their household at home so they need to get education related to unfamiliar matters such as basic legal understanding.

\section{Ahmadi women's contributions in external advocacy}

The advocacy on women's issues have been done in many places. Summarized from the research by Jarwati (2016) and Arisandi (2019) on advocacy for women as the victims of violence, advocacy is carried out with the aim of assisting victims to obtain justice and recover their psychological conditions. From both researches, advocacy activities for women as the victims of violence see the condition of women who tend to still feel traumatized, afraid, sad because they receive stigma, and experience intimidation when bringing their case to the law. They aim to resolve cases of violence against women using mediation and litigation. If mediation (non-litigation) approach is not working, then litigation is used. In this paper, Ahmadi women in Tasikmalaya are seen as women who have transformed from victims of intolerance into survivors and advocacy actors who, together with their advocator and mediator, excecute advocacy based on Rights and Social Inclusion-approach.

The awareness of rights is a fundamental part of advocacy process. Advocacy requires a common perception from all parties involved, especially the survivors who in this case are JAI members. Conversely, inequality of understanding has the potential to inhibit the advocacy. In fact, according to Komnas Perempuan's report regarding the process of advocacy against women as victims of violence, difference in perception that are not resolved potentially repeat the violence (Subiyantoro, 2006: 25) because the victim is not totally understanding about how to deal with the violation of the rights. 
After holding Internal Advocacy, Ahmadi women in Kersamaju started to take a part on the advocacy, brave enough to contributed in External Advocacy by visit the excluders including P3N Officer and the local Village Head. The External Advocacy divided into three parts: advocacy demands the right to use the mosque, advocacy demands equal access for marriage registration, and advocacy to be involved in village activities.

First, advocating for places of worship. After internal group awareness was sufficiently awakened, JAI Kersamaju members continued the renovation of the mosque while measuring the situation, monitor the response of the excluders, and without removing the seal installed in front of the mosque. When the renovation was done, number of excluders including from MUSPIKA (Musyawarah Pimpinan Kecamatan/ District Leaders Forum) of Cigalontang Sub-district, Bakorpakem (Badan Koordinasi Pengawasan Aliran Kepercayaan dan Keagamaan/Coordinating Board for Monitoring Beliefs and Religions), P3N officers, and Satpol PP (Satuan Polisi Pamong Praja/Civil Service Police Units) came to JAI Kersamaju and were accepted at the E's house.

With better understanding and skills, Ahmadi women try to face the excluder. It was decided that $\mathrm{N}$ and $\mathrm{A}$ would meet the excluders at E's house. Although they were still afraid, they slowly explained that there was no proper legal basic to prohibit the renovation and the use of the mosque. "SKB also has no point of prohibiting mosque building, they prohibit the spread of teachings. We are not inviting or force (people to join Ahmadiyya)," said $\mathrm{N}$ and $\mathrm{A}$. After hearing the response, the excluders which all men, said that they only monitoring the mosque and left the house.

The seal at Al-Furqon makes Ahmadi feel unsafe to worship even though the building had been completely renovated. In order to negotiate to use the mosque safely, an Ahmadi woman named $\mathrm{H}$ communicate with $\mathrm{O}$, the $\mathrm{P} 3 \mathrm{~N}$ Officer. She questioned why the mosque was sealed, and $\mathrm{O}$ asked back why Ahmadi did not mingle with the community and instead built their own mosque. $\mathrm{H}$ explained that they did not intend to distinguish themselves from others, but indeed there is no mosque near her home in Gadel, so they had to walk far enough to other part of villages just to do daily worship. While at the same time, ironically, $\mathrm{O}$ was built a mosque and boarding school behind his house even though there is already a mosque in front of his house. $\mathrm{H}$ replied to $\mathrm{O}$ by saying, "You're building a boarding school 
and a mosque right behind (your house)? Now that's the mosque (in front of your house), we can see the roof of the mosque from your house. Why you can (build a mosque), but I can't?"

O just smiled, then said, "Fine, just use the mosque, as long as you aren't removing the seal. Ahmadi is so headstrong." That answer was considered as O's agreement that Ahmadi can use the mosque, without removing the seal. Because if they remove the seal, it might "provoke" the excluder to come and intimidating them.

Secondly, advocacy for marriage registration. In addition to demanding the right to use the mosque, $\mathrm{H}$ also visited $\mathrm{O}$ several times to discuss about the Marriage Registration. When $\mathrm{H}$ planned to get married in 2019, he went to $\mathrm{O}$ and questioned the reason why it is so difficult for Ahmadi to register their marriage in Kersamaju. O explains, the Statement Letter signed by each Ahmadi is not officially from the local KUA. The letter made by P3N Kersamaju does not have letterhead, it only contains the data of the Ahmadi, including name, parent's name, place and date of birth, religion, address, and statement saying that the one who sign it is "not part of the Ahmadi Community." At the bottom of the letter there is room for the autograph of the author, witnesses, and stamp. $\mathrm{H}$ assumed the letter was an evidence of law violation committed by the village apparatus because it abolishs Ahmadi rights. "He said we violate the law. By abolishing the rights of others, don't (they) violate the law? While us, which law are we violating?" said $\mathrm{H}$.

When another Ahmadi do the safe way by getting married in Tenjowaringin so they don't have to deal with $\mathrm{P} 3 \mathrm{~N}$ officers, $\mathrm{H}$ took different step. She wants to get married in her own village, and she is okay if for this time she has to unresgistered their marriage or "menikah siri," which is a marriage by Islami Law (Sharia) without registered in the KUA. According to her, Nikah Siri is part of her process to claim her rights. She is fine even though she has no marriage certificates in order to fight, while women in unregistered marriage likely to be vulnarable.

Together with JAI Kersamaju, H reported the difficulties of marriage registration to the Indonesian Ombudsman. The Ombudsman responds by calling the Religious Affairs Office in that region and scold them for the difficulties of Ahmadi marriages.

The third is advocacy in village activities. During the time, Ahmadi was not involved 
in religious or public activities in the village. If Internal Advocacy focuses on the Rights approach, then External Advocacy considers the importance of a Social Inclusion-based approach. The two advocacy approaches were used simultaneously by DPC Peradi and Lakpesdam NU, including the Residents Forum, Posbakum, Kadarkum, and RBM.

In Kersamaju, $\mathrm{N}$ involved as a Posbakum's secretary. To advocate and approaching the village apparatus, $\mathrm{N}$ invites Ahmadi women to be active in village activities and to attend monthly recitation sessions in the village which they avoid before because of the hate speech. X, the village apparatus as well as the paralagel of Lakpesdam NU was the first village apparatus who invites JAI to mingle in village. The opportunity to be involved in the village events is an advocacy tool for JAI to introduce their identity which had been considered heretical. The meeting space between JAI and non-JAI residents, especially women, is able to uncover the stigma.

Meanwhile in Tenjowaringin, an Ahmadi woman named W was chosen as the Chief of RBM. RBM activities are focus on the issue of families and children with disabilities. In her work program, W also observed the importance of parenting education for young mothers. In the same village, $T$ was chosen as Chief of the BPD (Badan Permusyawaratan Desa/Village Consultative Board) as well as involved in handling Posbakum and Kadarkum. For T, her identity as Ahmadi woman made her fellows BPD Chief from other villages whose mostly men are underestimate her. She became a victim of the stigma that women could not lead, but $\mathrm{T}$ showed she is able to work as well as others, and that was proven by her leadership's quality. $\mathrm{T}$ is actively advocating problems in Tenjowaringin, including domestic violences. T herself already realized the importance of women's involvement and empowerment. As Ahmadi, $T$ felt it was important for women to represent themselves in public to minimize the stigma attached by society.

From what have been done by $\mathrm{W}$ and $\mathrm{T}$, it can be concluded that being involved as the Chief of RBM and the Chief of BPD in the village who also handles community issues such as domestic violences and child with disabilities will make Ahmadi women become more competent to not only handle the external problems, but also problems within their community. Advocacy on the issue of discrimination never stands alone but interconnected with other issues. 
In Kersamaju, Ahmadi also involved in religious events. After receiving internal reinforcement, Ahmadi women in Kersamaju feel more confident to attend the monthly recitation in the village. The relationship between the Village Head and Ahmadi has improved since N's involvement in Posbakum. Supported by Lakpesdam NU, the Village Head also began to attend JAI religious forums such as the Maulid Nabi (the birthday celebration of Prophet Muhammad). In addition, non-JAI residents began to attend the Ahmadi women's monthly forum called Muawannah. Every Muawannah, JAI invites lecturers to convey religious knowledge. During this Muawannah, women around the neighborhood were coming because they were interested in the themes of the lectures.

Advocacy steps to connect JAI with villagers also have been done through the Citizens Forum. On that forum, Ahmadi established relationships with their neighborhood by discussing general topics such as village activities, entrepreneurship, and personal hobbies. This potentially build a new bridge between them and connect them as fellow citizens, without divided but their specific background.

The advocacy assisted by Lakpesdam NU and DPC Peradi finally open the spaces for Ahmadi to contribute in village activities. N, A, H, K, and E choosen as the organizer of Polling Station Working Committe (Kelompok Penyelenggara Pemungutan Suara/KPPS) in their district by the Village Head. Related to the terror occurred every Eid, Lakpesdam NU advocated the village apparatus and issued a letter of notification to prohibiti the takbir keliling (surround the village and recite the God's names) every Eid night, so that Ahmadi in Kersamaju feel more peaceful.

Meanwhile in Sukapura, the same programs have been done by Lakpesdam NU and DPC Peradi including the establishment of Posbakum and Paralegal Training, but there is no significant progress of the advocacy in Sukapura because the lack of actors and low awareness of human rights. Therefore, JAI of Sukapura and the mediators need to be more focus on building the internal advocacy to strengthen their understanding of Rights and law.

As mentioned before, women peculiarly have certain all-women space in village activites like PKK and Posyandu. Ahmadi women in three villages already join those two and there are no specific problems in relations between Ahmadi women and local residents. The involvement of Ahmadi women in those activities are quite important for create 
inclusiveness, but still not too effective to influence local policies among elites who are discriminate Ahmadi in those area.

The combination of advocacy based on the Social Inclusion and the Rights-based approach is important to consider because these approaches emphasize the importance of community acceptance, open the services access, and policy changes towards marginalized groups. But the progress that has been achieved doesn't mean that the advocacy is finished. Because, Ahmadi still have to sign a statement letter before marriage and he mosque in Kersamaju also still sealed. For D himself, he feels like there is a "time bomb" in his village that could explode at anytime. Only if there is no more discrimination against them, then it can be said that advocacy efforts have been successful. This is why, advocacy must be seen as a continuously struggle process.

\section{Conclusion}

This research attempts to look at advocacy process from the perspective of survivors. It was found that Ahmadi women in the villages of Kersamaju, Sukapura, and Tenjowaringin had experienced intolerance. It made them traumatized, but at a certain point it was able to transforms women from object into subject of advocacy and become the Change Agent for their group.

The Ahmadi in Tasikmalaya is advocated by DPC Peradi through Rights-based advocacy and Lakpesdam NU through Social Inclusion-based advocacy approach. Lakpesdam NU helped to assist JAI members and excluders in the villages by train the actors who can accommodate the need of two parties. While DPC Peradi focuses on Paralegal training and develop Paralegal actors as mediators who care, accompanied, and defend JAI members. The combination of two approaches give positive impacts for Ahmadi's struggle. Paralegal training increases the understanding about protection for citizens, while cultural approach helps JAI members to be more open of their relation with villagers through social activities.

In the advocacy process, resistance from internal JAI occurs and potentially impede the advocacy. For this reason, internal advocacy is important to provide legal understanding for survivors so they have the same perception and contribute in advocacy. The internal advocacy raises their awareness to form alliances with other communities. Finally, it is 
important for Ahmadi women to be involved because women experiences intolerance and they also able to build a way for an inclusive relation through women activities in the village.

In executing advocacy with a Rights-based approach, Ahmadi women learn about legal issues related to their cases through Awareness Class and Paralegal Training. Ahmadi women become the members of Posbakum, Kadarkum, and RBM too in their neighborhood. This helps them to empower themselves, the Ahmadiyya, and also the community around. Therefore, they are more confident to be involved in advocacy based on Social Inclusion, where women have actually been able to actively socialize through various activities in their villages but previously were somewhat impeded by discrimination from residents. Empowerment helps to increase their self-confidence and participate in village activities. So, it might be concluded, women can involve in the advocacy process with both types of approaches.

Advocacy efforts through various programs such as Paralegal Training, Posbakum, Kadarkum, and RBM are gaining number of progress. Ahmadi are more aware about the need to blend with the local residents. JAI's involvement in village programs makes them also brave and care with the problems in community, including issues like domestic violence. Lakpesdam NU and DPC Peradi effectively involved JAI in the advocacy process and place JAI members as advocacy actor, not only as victim. Thus, advocacy will be more sustain because victims are included as actors who advocate themselves and their groups.

\section{Bibliography}

Ahmad, Hariadi. "Pengembangan Panduan Pelatihan Self-Advocacy Siswa SMP", Jurnal Pendidikan Humaniora, Vol. 1, No. 2 (2013): p. 190-199.

Arisandy, Ardita. "Advokasi Sosial Perempuan Korban Kekerasan Seksual (Studi Pada Woman Crisis Centre Dian Mutiara, Malang)". Graduation paper: Universitas Muhammadiyah Malang, 2019.

Bhaskara, Ign. L. Adhi, "Yang Terjadi di Balik Pembubaran Diskusi Buku Ahmadiyah Bandung (internet)". Tirto.id. (https://tirto.id/yang-terjadi-di-balik-pembubarandiskusi-buku-ahmadiyah-bandung-dd9e) (accessed on December, 19th 2019).

Chadijah, Devi Intan, Aan Kosihan, Irma Juraida. "Morphogenetic Kebudayaan dalam Sistem Mata Pencaharian Masyarakat Desa Tutup Ngisor, Kabupaten Magelang.” Community, Vol. 6, No. 1 (2020): p. 104-119. 
ljtihad: Jurnal Wacana Hukum Islam dan Kemanusiaan, Volume 20, No. 2, Desember 2020: 191-210

Gani, Irwan. "Pemberdayaan dalam Perspektif Stakeholders: Pengungkapan Makna Pemberdayaan Masyarakat Wilayah Pesisir Kabupaten Kutai Kartanegara”. Bekasi: Red Carpet Studio, 2011.

Jarwati, Sri. "Advokasi Perempuan dan Anak Korban Kekerasan dalam Rumah Tangga (Studi Peran Koalisi Perempuan Indonesia (KPI) Kota Salatiga Tahun 2010-2015)", Graduation paper: IAIN Salatiga, 2016.

Maarif, Samsul, Husni Mubarok, Laela Fitriani Sahroni, Dyah Roessusita. "Merangkul Penghayat Kepercayaan Melalui Advokasi Inklusi Sosial: Belajar Dari Pengalaman Pendampingan”. Yogyakarta: CRCS UGM, 2019.

Mudzakkir, Amin. "Minoritisasi Ahmadiyah di Indonesia", dalam Masyarakat Indonesia: Majalab Ilmu-Imu Sosial Indonesia, Ed. Vol. XXXVII No.2 (2011): p. 1-24.

Noor, Nina Mariani, Siti Syamsiyatun, JB. Banawiratma, "In Search of Peace: Ahmadi Women's Experiences in Conflict Transformation", dalam Ijtihad, Jurnal Wacana Hukum Islam dan Kemanusiaan Vol. 15, No. 1, (2015): p. 61-82.

Panggabean, Samsu Rizal, Mohammad Miqdad, Asfinawati, Ram Kakarala, Zainal Abidin Bagir. "Mengelola Keberagaman dan Kebebasan Beragama di Indonesia: Refleksi atas Beberapa Pendekatan Advokasi”. Yogyakarta: CRCS UGM, 2014.

Subiyantoro, Eko Bambang. "Advokasi Anti Kekerasan terhadap Perempuan: Pengalaman Forum Belajar Bersama Komnas Perempuan”. Jakarta: Komnas Perempuan, 2006. 